UDC 342.951

DOI https://doi.org/10.32847//n.2020.11.30

Yarova A.Ye.

PhD Student of the Department of Administrative Law and Administrative Activities Yaroslav Mudryi National Law University

\title{
OFFENCES RELATED TO THE CONFLICT OF INTEREST MANAGEMENT IN THE HEALTHCARE SECTOR: ELEMENTS, SIGNS AND ADMINISTRATIVE LIABILITY
}

Problem Statement. Efficient anticorruption interventions in the public healthcare sector require application of a complex approach by public authorities to ensure the successful implementation of the Anti-Corruption Policy. Priority under these conditions should be given to eliminating the causes and conditions that lead to commissioning of corruption offences [1, p. 53], including those in the healthcare sector. A conflict of interests is a kind of factor that can lead to corrupt behaviour, in particular, by a healthcare authority or healthcare institution official, and creates preconditions for the abuse of entrusted power when the relevant subjects take their decisions or actions [2, p. 6]. Management of a conflict of interests is one of the most important anti-corruption mechanisms, which at the same time represents a method to ensure proper functioning of workrelated legal relations [3, p. 13]. The scope, signs and elements of administrative offences related to the conflict of interest management in the healthcare sector, have not been adequately addressed by researchers, suggesting the need to investigate this issue.

Review of the recent literature. The concept of administrative liability was studied by a number of researchers in Ukraine and abroad; among those were V.B. Averyanov, D.M. Bakhrakh ,Yu.P. Bityak, Z.S. Gladun, I.Ya. Senyuta, S.G. Stetsenko, T.O. Kolomoyets, O.M. Shevchuk, etc. For example, S.V. Knysh addressed the issue of a legal liability for offences in the healthcare sector [4], M.V. Spivak studied legal regulations of an administrative liability in the healthcare sector [5]. O. Dotsenko described characteristics of an administrative liability for offences in the healthcare sector [6]. A.B. Kasumova identified types of administrative offences, the subject of which were healthcare workers [7]. O. Babich described aspects of corruption offences in the field of medical activities [8]. M.V. Okereshko defined the scope and identified the elements of administrative offences committed by doctors in the healthcare sector [9]. However, characteristics of violation of the law on conflict of interest management in the healthcare sector are poorly described in scientific literature, indicating the relevance of the chosen subject of the study and its practical significance.

The aim of the present paper was to investigate the scope, signs and elements of an administrative offence, which are related to the conflict of interest management in the healthcare sector.

Background and discussion. Article 1 of the Law of Ukraine on the Prevention of Corruption defines a «potential conflict of interests» and a «real conflict of interests» [10]. According to the Order of the Ministry of Health of Ukraine No.207 of March 27, 2012, «On Approval of the Audit Procedure in the System of the Ministry of Health of Ukraine», a «conflict of interests» is defined as a conflict between personal interests of an employee and his/her official duties at the department, which, if present, may affect his/her objectivity or impartiality in decision-making, as well as commissioning or non-commissioning of acts during performance of his/her official duties (item 1.2.) [11]. 


\section{АДМІНІСТРАТИВНЕ ПРАВО І ПРОЦЕС; ФIHAHСОВЕ ПРАВО; ІНФОРМАЦЙНЕ ПРАВО}

Article 80 of the Law of Ukraine «Fundamentals of Health Care Legislation of Ukraine», states that persons guilty of violating the health care legislation are subject to civil, administrative or criminal liability in accordance with the law [12]. According to the Law of Ukraine on the Prevention of Corruption, persons, specified in paragraph 1 of Article 3 of this Law, shall be held criminally, administratively, civilly and disciplinary liable for corruption and corruption-related offences [10]. Therefore, there is a legislatively established administrative liability for violations of the conflict of interest management regulations in the healthcare sector. Administrative liability for violations of the law on the conflict of interest management in the healthcare sector serves for prevention of a conflict of interests.

Violations of the conflict of interest management regulations in the healthcare sector should be referred to corruption-related offences. For example, Article 1 of the Law of Ukraine on the Prevention of Corruption defines a «corruption-related offence» as an act that does not contain any signs of corruption, but violates the requirements, prohibitions and restrictions established by this Law, committed by the person specified in paragraph 1 of Article 3 of this Law, for which the law establishes criminal, administrative, disciplinary and/or civil liability [10]. This means that the offences committed by the persons subject to administrative liability for violation of the law on the conflict of interest management in healthcare, do not have any signs of corruption, but such offences involve violations of the requirements, prohibitions and restrictions provided for by the provisions of the Law of Ukraine on the Prevention of Corruption.

According to Article 9 of the Code of Ukraine on Administrative Offences, an administrative offence (misdemeanour) is a unlawful, culpable (intentional or negligent) action or inaction that offends public order, infringes property, interferes rights and freedoms of citizens, offends the established order of management and for which an administrative liability is provided by the law
[13]. N.P. Bortnyk and L.V. Bilinska suggest that the administrative liability for corruptionrelated offences is a type of legal liability (along with a criminal, disciplinary and civil liability), which includes imposition by an authorized body or an official of an administrative penalty on a person who has committed a corruption-related administrative offence $[14$, p. 31$]$. That means that the administrative liability for violations of the law on the conflict of interest management in healthcare is a type of a legal liability. Addressing the issue of the legal responsibility of a healthcare worker, S.G. Stetsenko defines such liability as an imposition on a person who committed an offence while performing professional duties in the healthcare sector, of state enforcement actions, provided for by law, involving certain losses of a personal, organizational or property nature which the guilty party will have to bear $[15$, p. 254].

The administrative liability for offences provided for by the Code of Ukraine on Administrative Offences is imposed in the event that the nature of such offences does not entail the criminal liability according to the law (paragraph 2 of Article 9). The administrative liability applies to persons who have committed an administrative offence under the law in force at the time and place of the offence (Article 8) [13].

The research literature lacks a widely accepted definition of an administrative liability. For example, Yu.P. Bytyak understands an administrative liability as an imposition of administrative penalties on persons who have committed an administrative offence (misdemeanour), whereby such penalties entail aggravating consequences of a material or moral nature [16, p. 261]. V.K. Kolpakov states that an administrative liability is a specific response of the state to an administrative offence, which involves the imposition of a penalty provided by law, on the subject of the offence by an authorized body or official [17, p. 289]. According to T.O. Kolomiets, an administrative liability is a specific form of a negative response of the state represented by authorized public authorities, 


\section{АДМІНІСТРАТИВНЕ ПРАВО І ПРОЦЕС; ФIHAHСОВЕ ПРАВО; ІНФОРМАЦЙНЕ ПРАВО}

to the relevant category of illegal actions. And the persons who have committed such offence shall be held liable to the authorized state body for their illegal actions, and to be imposed an administrative penalty as appropriate in the order determined by the current legislation of Ukraine [18]. S.V. Rivchachenko, in his study of the conflict of interest management as an anti-corruption measure, indicates that an administrative liability is a compulsory, in accordance with the established procedure, use of enforcement actions by a legitimate subject, provided for by law for commissioning of an illegal act by an offender [19, p. 103]. Therefore, an administrative liability is the imposition of penalties by an authorized body(s) or an official(s) to persons who have committed an administrative offence (misdemeanour). Types of illegal acts must be provided for by the current legislation.

Violations of law in the public healthcare, with infringement on such values as human life and health, should be considered a public offence and they bear such signs of administrative offence as a social harm (danger), unlawfulness, guiltiness of a person who has committed an offence; punishability of an illegal action by an administrative penalty $[9$, p. 80,81$]$. This conclusion can be used in our study. Therefore, violation of the requirements of the management of conflict of interests in the healthcare sector can be referred to an administrative offence in the presence of the following signs: 1) social harm (danger); 2) unlawfulness; 3) guiltiness; 4) punishability by an administrative penalty.

The Code of Ukraine on Administrative Offences states that a failure to self-report in the cases and in the manner prescribed by law a real conflict of interests shall be considered an administrative misdemeanour (paragraph 1 of Article $172-^{7}$ ). According to the note to this Article, the liable subjects are the persons specified in items 1, 2 of paragraph 1 of Article 3 of the Law of Ukraine on the Prevention of Corruption. However, if there is evidence, informed not necessarily in writing but also orally, provided by a manager that the person has a real conflict of interest, the liability shall be excluded (paragraph 1 of Article 172- ${ }^{7}$ ) [13].

Violation of the law on the conflict of interest management in the healthcare sector is a certain legal fact characterized by the presence of a set of elements of an offence. According to V.A. Kolpakov and O.V. Kuzmenko, the elements of an administrative offence should include a set of objective and subjective signs established by administrative legislation, in the presence of which the act shall be considered an administrative offence [20, p. 48]. The subject of an administrative offence is a natural person who has reached 16 years at the time of commitment of an administrative offence. At the same time, all subjects of administrative offences are divided into general and special. The special subject is a subject who, in addition to its general features (i.e. those inherent to all subjects of administrative offences, such as sanity, age of administrative liability, etc.), bears also special ones [21, p. 7]. Such special features include those that indicate the specifics of the legal status of the subject of the offence, such as being an official. The object of an administrative misdemeanour includes public relations regulated by legal provisions protected by administrative sanctions. When analysing an object of a misdemeanour as its element, characteristic features of the object should be identified [6, p. 129]. The objective element of an administrative offence is characterized by such signs as an illegal act (action or inaction), socially harmful (dangerous) consequences, causal relationship between the action and the consequences, the place and time, situation, manner and means of committing the misdemeanour. The subjective element of a misdemeanour includes the guilt, motive and purpose of behaviour of an offender [16, c. 267-268].

The set of elements of the administrative offence related to the conflict of interest management in the healthcare sector should include the following: the object, the subject, the objective element and subjective element. The 


\section{АДМІНІСТРАТИВНЕ ПРАВО І ПРОЦЕС; ФIHAHСОВЕ ПРАВО; ІНФОРМАЦЙНЕ ПРАВО}

object is a violation of requirements related to the conflict of interest management. The objective element is a disposition of elements (action or inaction). In our case, it is a failure to self-report in the cases and in the manner prescribed by law a real conflict of interests, and taking actions or making decisions under circumstances of a real conflict of interests. The subject of an offence is a person who has committed the offence and to whom an administrative penalty may be applied. The subject of an offence, in our case, includes officials of legal entities under public law in the healthcare sector. The subjective element is an internal (mental) attitude of the subject of an offence to the act he/she has committed and to its harmful effects. It can be divided into two forms: intent and negligence. Such offence in the healthcare sector is committed only intentionally. The signs of the subjective element include: guilt, purpose and motive for the offence. In our case, this is a priority of private interests of an official of legal entities under public law in the healthcare sector over his/her official duties, which interests, if present, may affect his/her objectivity or impartiality in decision-making, as well as commissioning or non-commissioning of acts during performance of his/her official duties. It should be noted that neither the law nor the relevant scientific literature provides a list of persons who belong to «officials of legal entities under public law» in the healthcare sector. For example, such persons may include both the head of department or the head of the entire health care facility or just a physician [8, p. 17].

Next, we should provide some examples of legal cases related to violation of the law on conflict of interest management in the healthcare sector. Example 1. Person-1, holding a position of the Deputy Chief Medical Officer and acting for the Chief Physician of the public healthcare institution «N Central District Hospital», voted for the approval of the bonus payment to his/her salary in 2016 in the amount of 10 thousand $\mathrm{UAH}$, and in 2017 again in the amount of 10 thousand UAH, did not inform the members of the Committee of the existence of a conflict of interests. Actions of this persons demonstrate the elements of an administrative offence, provided for by paragraph 1 and paragraph 2 of Article $172-^{7}$ of the Code of Ukraine on Administrative Offences [23]. Therefore, Person-1, failed to inform the members of the Committee of the presence of a conflict of interests and a had a conflict between his private interest (property interest) and official functions (such as the right to influence the amount of benefits depending on the volume of his personal contribution to the work of the institution), which respectively affected the objectivity and impartiality of his actions. The private interest of Person-1 involved a material interest, namely the ability to freely receive a bonus estimated by the self-evaluated volume of his personal contribution to the work of the institution. Example 2. Some Person, being a Chief Physician at a public healthcare institution of the $\mathrm{N}$ District Council, signed a petition to the health department of the N District Public Administration «On awarding bonuses for health care workers» regarding payment of a cash bonus to him (as a Chief Physician of the said public healthcare institution) based on the results of his work in the second half of 2016, in the amount of in the amount of $500 \%$ of the salary, on the basis of which the acting Head of the said department in 2016 issued an order to award bonuses to this Person [24]. Therefore, the Person (the Chief Physician of the public healthcare institution) is guilty of committing offences provided for by paragraph 1 and paragraph 2 of Article $172-^{7}$ of the Code of Ukraine on Administrative Offences, as this Person acted in a situation of a real conflict of interests.

In case of establishment of an administrative liability, offences related to the conflict of interest management in the healthcare sector, entail imposition of administrative penalties in form of a fine, and, in some cases, deprivation of the right to hold certain positions or perform certain activities for a certain period of time. Thus, the Code of Ukraine on Administrative Offences states that a failure to self-report in the cases and in the manner prescribed by law a real conflict of interests shall be considered 


\section{АДМІНІСТРАТИВНЕ ПРАВО І ПРОЦЕС; ФIHAHСОВЕ ПРАВО; ІНФОРМАЦЙНЕ ПРАВО}

an administrative misdemeanour and entails the imposition of a fine in the amount of 100 to 200 minimum non-taxable incomes. (paragraph 1 of Article $172-^{7}$ ). Committing actions or taking decisions in a situation of a real conflict of interests entails the imposition of a fine in the amount of 200 to 400 minimum non-taxable incomes (paragraph 2 of Article 172-7). Actions provided for in paragraphs 1 or 2, committed by a person who within the past year was subject to administrative penalties for the same violations, entail the imposition of a fine in the amount of 400 to 800 minimum non-taxable incomes with deprivation of the right to hold certain positions or engage in certain activities for a period of 1 year.

Conclusions. Violation of the law on the conflict of interest management in the healthcare sector should be referred to corruption-related offences. Such offences should be referred to public offences. An administrative liability for these violations is a type of the legal liability. An administrative offence related to the conflict of interest management in the healthcare sector is characterized by the following signs: 1) social harm (danger); 2) unlawfulness; 3) guiltiness; 4) punishability by an administrative penalty.

Elements of an administrative offence related to the conflict of interest management in the healthcare sector include characteristics of an object, subject, objective and subjective elements. The object is a violation of requirements related to the conflict of interest management. The objective element is a failure to self-report in the cases and in the manner prescribed by law a real conflict of interests, and taking actions or making decisions under circumstances of a real conflict of interests. The subject includes officials of legal entities under public law in the healthcare sector. The subjective element is a priority of personal (private) interests of an official of legal entities under public law in the healthcare sector over his/ her official duties with the purpose of obtaining a cash or non-cash benefits.

\section{Summary}

This paper focuses on offences related to management of the conflict of interest in the healthcare sector, and defines the scope of administrative liability and administrative sanctions for these violations. It is determined that the administrative liability is the imposition of penalties by an authorized body(s) or an official(s) to persons who have committed an administrative offence (misdemeanour). It is justified that violations of the conflict of interest management regulations in the healthcare sector should be referred to corruption-related offences. It is further stated that the offences related to the conflict of interest management in the healthcare sector include violations of the requirements, prohibitions and restrictions provided for by the Law of Ukraine on the Prevention of Corruption.

The following signs of an administrative offence related to the conflict of interest management in the healthcare sector are identified: 1) social harm (danger); 2) unlawfulness; 3) guiltiness; 4) punishability by an administrative penalty. It is found that such offence includes the following elements: characteristics of an object, subject, objective and subjective elements. It is established that the object is a violation of requirements related to the conflict of interest management; the objective element is a failure to self-report in the cases and in the manner prescribed by law a real conflict of interests, and taking actions or making decisions under circumstances of a real conflict of interests; the subject includes officials of legal entities under public law in the healthcare sector. Subjective element is the priority of personal (private) interests of an official of legal entities under public law in the healthcare sector over his/her official duties. The paper provides examples of legal cases related to the offences of the conflict of interest in the healthcare sector and imposition of administrative penalties pursuant to Article 172-7 the Code of Ukraine on Administrative Offences for actions of health care workers in a situation of a real conflict of interests. It is concluded that administrative offences related to the conflict of interest management in the healthcare sector should be referred to public offences. 


\section{АДМІНІСТРАТИВНЕ ПРАВО І ПРОЦЕС; ФIНАНСОВЕ ПРАВО; ІНФОРМАЦЙНЕ ПРАВО}

Key words: conflict of interests, health care, corruption-related offences, definition of an offence, signs of an offence, elements of an offence, administrative liability, conflict of interest management.

\section{Ярова А.С. Правопорушення, пов'язані із запобіганням і врегулюванням конфлікту інтересів у сфері охорони здоров'я: склад, ознаки й адміністративна відповідальність \\ Анотація}

У статті досліджено особливості правопорушень, пов'язаних із запобіганням і врегулюванням конфлікту інтересів у сфері охорони здоров'я, а також розкрито зміст і санкції адміністративної відповідальності за такі порушення. Установлено, що адміністративна відповідальність - це застосування стягнень уповноваженими органами або посадовою особою до осіб, які вчинили адміністративне правопорушення (проступок). Аргументовано, що порушення вимог законодавства щодо запобігання та врегулювання у сфері охорони здоров'я варто зарахувати до правопорушень, пов'язаних із корупцією. Розкрито, що правопорушення, пов'язані із запобіганням і врегулюванням конфлікту інтересів у сфері охорони, полягають у порушенні вимог, заборон та обмежень, передбачених Законом України «Про запобігання корупції».

Визначено ознаки адміністративного правопорушення щодо запобігання та врегулювання конфлікту інтересів у сфері охорони здоров'я, а саме: 1) суспільна шкідливість (небезпека); 2) протиправність; 3) винність; 4) адміністративна караність. 3'ясовано, що склад такого правопорушення включає в себе ознаки, які характеризують об'єкт, суб'єкт, об' єктивну та суб'єктивну сторони. Установлено, що об'єкт - це порушення вимог щодо запобігання та врегулювання конфлікту інтересів; об'єктивна сторона - неповідомлення особою в установлених законом випадках і порядку про наявність у неї реального конфлікту інтересів і вчинення дій чи прийняття рішень в умовах реального конфлікту інтересів; суб'єктом є посадові особи юридичних осіб публічного права у сфері охорони здоров'я. Суб'єктивна сторона - це пріоритет особистих (приватних) інтересів посадової особи, юридичних осіб публічного права у сфері охорони здоров'я перед їхніми службовими обов'язками. Наведено приклади судових справ щодо правопорушення законодавства з питань запобігання та врегулювання у сфері охорони здоров’я, застосування адміністративної відповідальності за ст. 172-7 Кодексу України про адміністративні правопорушення за дії осіб закладів охорони здоров'я в умовах реального конфлікту інтересів. Зроблено висновок, що адміністративні правопорушення, пов'язані із запобіганням і врегулюванням конфлікту інтересів у сфері охорони здоров'я, варто зарахувати до публічних правопорушень.

Ключові слова: конфлікт інтересів, охорона здоров'я, правопорушення, пов'язані з корупцією, поняття, ознаки, склад правопорушення, адміністративна відповідальність, запобігання та врегулювання конфлікту інтересів.

\section{References:}

1. Співак М.В. Корупційні правопорушення у сфері охорони здоров'я: аналітичний аспект. Публічне право. 2013. № 3 (11). С. 53-60.

2. Політики і практики запобігання конфлікту інтересів у дев'яти країнах ЄС. Порівняльний аналіз. Документ SIGMA № 36. C. 6. URL: http://www.sigmaweb.org/ publications/39584967.pdf

3. Чаннов С.Е. О направлениях активизации деятельности комиссий по урегулированию конфликтов интересов. Административное право и процесс. 2011. № 5. С. 13-17.

4. Книш С.В. Юридична відповідальність за правопорушення у сфері охорони здоров'я в Україні. Право і безпека. 2018. № 4 (71). С. 43-48. 


\section{АДМІНІСТРАТИВНЕ ПРАВО І ПРОЦЕС; \\ ФIНАНСОВЕ ПРАВО; \\ ІНФОРМАЦЙНЕ ПРАВО}

5. Співак М.В. Правове регулювання адміністративної відповідальності в галузі охорони здоров’я населення : автореф. дис. ... канд. юрид. наук / Нац. акад внутр. справ України. Київ, 2010. 16 с.

6. Доценко О. Адміністративна відповідальність за правопорушення в галузі охорони здоров’я населення. Підприємство господарство і право. 2017. № 1. С. 128-132.

7. Касумова А.Б. Адміністративні правопорушення, суб'єктом вчинення яких є медичні працівники. Науковий вісник Ужгородського національного університету. Серія «Право». 2016. Т. 2. Вип. 37. С. 7-9.

8. Бабич О. Правовий аспект корупційних правопорушень у сфері медичної діяльності. Упр. закл. охорони здоров'я. 2011. № 9. С. 14-19.

9. Окерешко М.В. Поняття і склад адміністративного правопорушення вчиненого лікарем у сфері охорони здоров’я населення. Молодий вчений. 2017. № 5.1 (45.1). С. 80-84.

10. Про запобігання корупції : Закон України від 14.102014 № 1700-VII. URL: http://zakon2.rada.gov.ua/laws/show/1700-18 (дата звернення: 04.05.2020).

11. Про затвердження Порядку проведення аудиту в системі Міністерства охорони здоров'я України : Наказ Міністерства охорони здоров’я України від 27.03.2012 № 207. URL. http://www.moz.gov.ua/ua/portal/dn_20120327_207.html (дата звернення: 05.05.2020).

12. Основи законодавства України про охорону здоров'я : Закон України від 19.11.1992 № 2801-XII. Відомості Верховної Ради Украӥни. 1993. № 4. Ст. 19.

13. Кодекс України про адміністративні правопорушення : Закон України від 07.12.1984 № 8073-Х. Відомості Верховної Ради УРСР. 1984. № 52. Ст. 1122.

14. Бортник Н.П., Білінська Л.В. Адміністративна відповідальність за правопорушення, пов'язані з корупцією. Вісник Національного університету «Львівська політехніка». Серія «Юридичні науки» : збірник наукових праць. 2016. № 845. С. 28-33.

15. Медичне право України : підручник / за заг. ред. С.Г. Стеценка. Київ : Правова єдність, 2008. $507 \mathrm{c}$.

16. Адміністративне право : підручник / за ред. Ю.П. Битяка. Харків : Право, 2020. 392 с.

17. Колпаков В.К. Адміністративне право України : підручник. Київ : Юрінком Інтер, 1999. 736 с.

18. Коломієць Т.О. Структура адміністративної відповідальності: сучасний доктринальний погляд. Підприємництво, господарство і право. 2002. № 4. С. 65-66.

19. Рівчаченко С.В. Запобігання та врегулювання конфлікту інтересів як спосіб протидії корупції : дис. ... канд. юрид. наук. Запоріжжя, 2017. 195 с.

20. Колпаков В.К., Кузьменко О.В. Адміністративне право України: підручник. Київ : Юрінком Інтер, 2003. 544 c.

21. Касумова А.Б. Адміністративні правопорушення, суб'єктом вчинення яких є медичні працівники. Науковий вісник Ужгородського національного університету. Серія «Право». 2016. Т. 2. Вип. 37. С. 7-9.

22. Постанова Доманівського районного суду Миколаївської області від 18 травня 2018 р. у справі № 475/368/18. URL: http://www.reyestr.court.gov.ua/Review/74076870

23. Постанова Апеляційного суду Тернопільської області від 28 вересня 2017 року у справі № 606/861 URL: http://www.reyestr.court.gov.ua/Review/69289831 